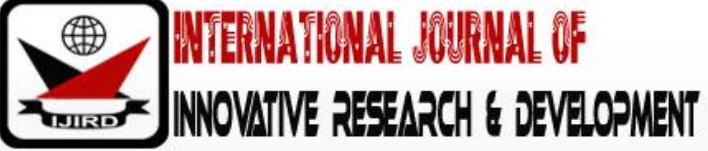

ISSN 2278 - 0211 (Online)

\section{External Financing and Performance of Manufacturing Firms in Nigerian Food Industry (2006-2016)}

\author{
Dr. Afolabi, Babatunde \\ Associate Professor, Department of Banking and Finance, College of Social and Management Sciences, \\ Afe Babalola University, Ado-Ekiti, Ekiti State, Nigeria \\ Dr. Olutoye, E. Adedayo \\ Senior Lecturer, Department of Entrepreneurship, College of Social and Management Sciences, \\ Afe Babalola University, Ado-Ekiti, Ekiti State, Nigeria \\ Okafor Felix Ikechukwu \\ Ph.D. Student, Department of Banking and Finance, College of Social and Management Sciences \\ Afe Babalola University, Ado-Ekiti, Ekiti State, Nigeria
}

\begin{abstract}
:
The study investigated the effects of external financing on the performance of manufacturing firms in the Nigerian food industry in the period of 2006-2016, using panel regression technique. Secondary sources of data were employed and it was sourced from financial statements of 5 sampled manufacturing firms Nigeria. Dependent variable was proxied by return on assets (ROA) and independent variables were proxied by ratio of total debt to total assets (TDTA), ratio of long term debt to total assets (LTDTA), ratio of total equity to total assets (TETA) respectively. The findings revealed that, TDTA and TETA jointly have insignificant positive relationship with ROA while LTDTA has insignificant negative relationship with performance. The study concludes that external financing has significant impact on manufacturing firms in Nigeria and therefore recommends that, manufacturing firms in Nigeria should employ mixture of equity and debt in their financing options while long term debt should be kept at a barest minimum to guide against company being over levered, which may result in financial distress on the long run as it is indicated in the results obtained.
\end{abstract}

Keywords: External financing, performance, manufacturing firms, food industry

JEL Classifications: G21, L66, N17

\section{Introduction}

Finance can be referred to as monetary resources needed by firms(either newly born or it is ongoing) to run their businesses. This can be used to finance business expansion in terms of business diversification, purchase of equipment and machineries, purchase of stocks etc. Finance can either be sourced within or outside of the firm (Chechet \& Olayiwola, 2014). Those sourced within are called internal financing and it has to do with retain earnings from the business operations while the ones sourced outside the firm are called external financing. Choosing the mixture of these, remain the responsibility of the financial managers of firms to determine the proportion of equity capital anddebt capital, that is, an optimal capital structure.

According to Ubesie(2016), external financing means the mixture of equity, debt or hybrid securities. Equity is funds raised through sales of common stock at the financial markets which gives the investors(shareholders) the right to the equity participation in the company, sharing the profit in the form of dividend According to Dare and Olorunfemi, it include, paid-up share capital, share premium, reserves and retained earnings On the other hand, debt or debenture is a debt instrument of long term loan raised from the creditors of the company which can either be secured, unsecured, , floating or redeemable while the hybrid securities are preference shares which has the features of both equity and debt instrument. A firm is at liberty to choose any of these or their combinations in their capital structure decisions. However, decision on the best financing mix to adopt or employed in the firm rest on the financial manager or director of the firm

More importantly, in choosing either or combination of these alternatives, Dare and Sola(2010) and Ololade, Omotosho and Adeniyi(2017) said, external financing can take either of these forms. 100\% equity:0\% debt, 100\%debt: $0 \%$ equity and X\% equity and Y\% debt. From these three alternatives, the first option is that of the unlevered firm, that is, the firm that ceased from taking the advantage of leverage. The second option is that of a firm that has no equity capital. This choice may not actually be accurate or possible in the real life economic situation, because no provider of funds will invest his money in a firm without equity capital. This is what is denoted to as 'trading on equity'. Because it is the equity element that is present in capital structure that motivates the debt providers to give their scarce resources to the business (Pandey, 
2011; Chechet \& Olayiwola, 2014) while the third option is the most realistic one as it combines both a certain percentage of debt and equity in the capital structure and thus, the advantages of leverage (if any) are exploited

As a consequence of this, it became difficult to determine the best mixture of finances to employ by firms and this has been a major source of controversy among finance scholars (Oloyede and Akinmulegun, 2010; Ong \& Teh, 2011). In theory of capital structure, there are conflicts as to whether capital structure matters or not. From the Modigliani(1958) and Miller(1963) under corporation taxes, hypothesis that, the value of firm is independent of its debt policy. They assumed that corporate taxes do not exist, he said the value of the firm depend on the earnings and the risk of the assets, however, in reality, corporate income taxes exists. On the other hand, the net income and traditional views are of the opinion that capital structure matters, they said, firms that include debt in its financing options, would have its value of firm increase and weighted average cost of capital decrease. Although, traditional view stated that this can only be achieved up to certain level of debt. The approach clearly implies that WACC decrease only within a reasonable limit of financial leverage after which their start increasing the financial leverage.(Dare and Olorunfemi, 2010; Pandey,2011; Hillier, Clacher, Ross, Westerfield, Jaffe \& Jordan, 2011) As a result of these divergent views from capital structure, it is therefore expected by the financial director or controller of the company to give best finance advice to the board for the purpose of adopting type finance that will enhance the performance of the firm.

From the empirical literature, results emanating from the literature have been mixed. While some tend to support the use debt in the financing options of firms, some are in support of equity financing option. However, the are other studies that are of the opinion that both debt and equity at appropriate percentage should be employed. More importantly, several studies on external financing in Nigeria concentrated on banks, this study shifted from this to manufacturing firms especially, and those firms in the food industry in Nigeria. In addition, in measuring performance of firms, several studies employed ROA, ROE, ROCE as proxy for performance however, net interest margin as a performance measure is not concentrated on by other studies. Therefore, this study examined the effects of external financing on performance of manufacturing firms in Nigeria and it also investigated the nexus between the impact of debt or equity on performance in the Nigerian manufacturing food industry.

\section{Literature Review}

\subsection{Concept of External Financing}

The two main sources of external financing available to firms are equity and debts (Pandey, 2011). The equities areowners of the firms and the profit divisible to them are the ruminants' after other interest holders have been serviced on the other hand, debt is that which is owed, either to creditor or money borrowed, but theterm can also cover moral obligations and other interactions not requiring money

Pandey (2011) stated that external financing which is explain under the purview of capital structure is used to measure the proportionate relationship between debt and equity by obtaining the debt and equity ratio which enables the financial manager to ascertain the number of times the equity of a company covers the debt obtained for a period. This define the degree of leverage employed by the firm in financing its operations, this affects the cost of capital and the value of the firm(Udoayang \& Asuquo, 2008)

From Saleemi, (2009) as cited by Onyango (2016), external financing is part of the total debt in a business that is owed to outsiders. This definition bring to light that external financing is sourced from outsiders and it forms part of the total debt of the company. The total debt of the company comprises the short term and long term loan

Rayan 2010 as cited by Mohammed (2017) says that, a firm that include debt in its capital structure do so with intention of maximizing, the benefits that comes with it and minimizing the cost associated with it. Financial leverage improves the profitability of firm but dilute the share value impacting on shareholders negatively as debt financing is costly. According to Swanson and Marshall (2008), debt is a means of using future purchasing power in the present before a summation is earned. A firm uses various kind of debt to finance its operations. The various types of debt can generally be categorized into; Secured and unsecured debt; private and public debt and syndicated and bilateral debt and other types of debt

External financing can be sourced through equity or debt instruments (Dare and Olorunfemi, 2010). Equity represents the value of ownership and interest the shareholders have. The company can raise equity by selling common and preferred stocks to investor which represent their ownership in the company, giving right to the owner to vote on corporate issues in proportion of their ownership in the company and the right to receive dividend payment. On the other hand, the debt instruments comprises of bond, debenture, bank loans, leasing. This crease fixed payment obligations to lenders. The lenders have priority claims in regular payment and principle. Therefore, a firm chooses the type of debt by the needs and purpose of financing.

\subsection{Financial Performance}

Financial act is measuring the firm's policies and processes in monetary terms. This also measure of firm's financial strength over a given period. From Stanwick, (2002) point of view, performance is expressed in terms of profits and losses, and this is observed by how a business performs over a given period of time. This position however limits financial performance indicators to profit and profitability aspects. This accounts for the past and present net results of the firm in relation to capital or assets utilized without the consideration of growth prospect that is a measure future performance.

According to Erasmus (2008) financial performance is considered as the best possible way of as to how a firm generates its' revenues through utilization of its assets. This connotes the ability of the firm to utilize the assets or capital 
at its disposal in generating returns over and over again. This bespeaks return on asset, return on equity and return on capital employed, which require accounting information for computation.

In measuring firm performances, different measures have been adopted and these measures have centered on productivity, profitability, growth or, even, customers' satisfaction. These measurements are Return on Investment (ROI), Residual Income (RI), Earning Per Share (EPS), Dividend Yield, Return on Assets (ROA), Growth in Sales, Return on Equity (ROE)Net Interest Margi (NIM) (Barbosa \& Louri, 2005). For the purpose of this study, performance is measured by three proxies namely; Return on Equity (ROE), Return on Assets (ROA) and Net Interest Margin (NIM)

The use of the Return on Assets (ROA) here is germane because it represents what firm earns on all assets held in a firm.On the other hand, Return on Equity (ROE) reflects how effectively a firm management in using shareholders' investment. It tells the shareholders how much the firm is earning on the book value of their investment. In fact, ROE is the most important measurement of firm's returns because it is influenced by how well the firm is performed on all other return categories, and indicates whether the firm can compete for private sources in the economy. ROE is defined as net income divided by average equity (Noraini, 2012).

Empirically, several measures have been employed by authors to measure the financial performance of firms. For example, Yimka et al,(2015) employed return on asset (ROA), return on equity (ROE)and return on capital employed(ROCE). Nassar, (2016) employed earning per share (EPS), return on equity (ROE) and return on asset(ROA). Bashiru and Bukar (2016) measure performance by employing return on assets and earning per share. Ubesie (2016) also measure performance with return on asset (ROA), return on equity(ROE) and asset turn over(AT).

It is however important to note that, in evaluating the performance of a firm, the wealth of a firm may influence the level of risk a company investor and managers may be ready to assume as well as fix the resources available to support the business. As a result of ownership and wealth incentive, it is important to investors and others to understand its effects on firm performance this is because capital structure decision on funding the assets (such as personnel, machinery and buildings) of an organization by debt or by equity will leave relationship with the final result for any given period. This is based on the fact that capital structure influences the returns and risks of shareholders and this consequently affects the market value of the shares.

\subsection{Theoretical Framework}

\subsubsection{Trade-off Theory of Capital Structure}

The theoretical underpinning of the study relied on the trade-off theory of capital structure. The theory is an extension of the Modigliani Miller (MM) theory which says thata firm's choice of its debt - equity ratio is a trade-off between its interest tax shields and the costs of financial distress. It further suggests that, firms in the same industry should have similar or identical debt ratios in order to maximize tax savings. The tax advantage among other features makes the after-tax cost of debt lower and hence the weighted average cost of capital will also be lower. Brigham and Gapenski (1996) argued that an optimal capital structure can be obtained if there exists, tax benefit which is equal to the bankruptcy cost. However increasing the amount of debt also increases the risk to a company, somewhat offsetting the decrease in the weighted average cost of capital(WACC). In all, the theory identifies a mix of debt and equity where decreasing WACC offsets the increasing financial risk to a company. It sought to establish an optimal capital structure where the weighted average cost of capital will be minimized, and the firm value maximized. At the optimum level of capital structure, tax advantage will be equal to bankruptcy costs. Among those who have used this theory in their respective work are Aliu, (2010) and AT-Tally, (2014)

\subsection{Empirical Review}

Chechet and Olatiwola (2014) studied the effect of capital structure on profitability of Nigerian quoted firms in Nigeria within the time scope of 2000-2009 using fixed-effects, random-effects and Hausman Chi Square estimations. Debt ratio and equity ratio was used as independent variable while dependent variable was proxy by profitability. The result revealed that debt ratio is negatively related with profitability while equity has positive relationship with profitability

Habiama (2014) studied relationship between capital structure and firm performance in emerging economy for data employed for 2014 using ordinary least square. Cross sectional data were and sourced employed from 18,876 firms operating in emerging economies. Dependent variable was proxy by return on equity (ROE) while independent variable was proxy by leverage, percentage of institutions, size, beta. The findings provide evidence that capital structure matters for firm's financial performance. Leverage is undesirably and meaningfully related to returns, and completely related to systematic risk. Overall, it was revealed that the findings support the static trade-off theory of capital structure; there is an optimal level of debt to equity ratio, above which the marginal benefit of financing capital with debt starts decreasing Alalade, Oguntodu and Adelakin (2015) examine the relationship between capital structure and profitability performance in the food product companies in Nigeria from 2009-2013 using panel regression analysis. Secondary data were employed from the financial statement of Dangote Sugar Refinery Plc, Honeywell Flour Mills Plc, Flour Mills Nig. Plc, Nestle Nig. Plc, Dangote Flour Plc and Multi-Trex Integrated Food Plc. Dependent variable were proxy by return on assets (ROA) return on equity (ROE) and return on capital employed( ROCE) while independent variable were equity and debt. The result revealed that revealed that gearing has no significant effect on ROA, ROE and ROCE.

Ubesie (2016) investigated the effect of capital structure on the financial performance of Nigeria quoted Conglomerates covering a period of 2011-2015 using descriptive and pooled regression analysis. Secondary data were employed from the financial statement of A.G. Leventis Nigeria Plc., Chellarams Plc., John Holt Plc., Scoa Plc., Transnational Corporation Plc., and UACN. Dependent variable were proxy by return on assets, ratio (ROA), return on equity ratio (ROE), 
assets turnover ratio (AT) and earnings per share whereas the independent variable were proxy by TD/TA, LTD/ TA, STD/ TA, and Firm size. It was found that capital structure has effect on both return on assets and asset turnover of the conglomerates but no effect on return on equity and earnings per share of the conglomerate

Obi and Imo (2016) accessed the impact of external financing on dividend per share of quoted manufacturing firms in Nigeria within a time framework of 1999-2012 using panel data analysis. Secondary data were employed and sourced from the financial statement of the selected firms. Dependent variable was proxy with dividend per-share while independent variable was proxy by asset structure, firms' size, and total debt. It was found that the external financing proxy by total debt has a negative and insignificant effect on the performance of firms in Nigeria

Bashiru and Bukar (2016) studied capital structure and its impact on the financial performance of listed firms in the Nigeria oil and gas industry in Nigeria from 2005-2014 panel regression analysis. Secondary data were employed and sourced from the financial statement of 7 firms in the Nigeria oil and gas industry. Dependent variable was proxy by return on assets(ROA) and on earning per share while independent variable were proxy by short term loans, long term loan, total debt, size and tangibility. It was revealed that there is a negative and significant relationship between capital structure and firm performance. It was also revealed that the result also shows that firm size and tangibility have positive and significant relationship with ROA and EPS.

Nasar (2016) evaluated capital structure and its effect on the financial performance of the firms in Borsa Istanbul from 2005-2013 using multivariate regression analysis. Secondary data were employed and sourced from 136 industrial companies listed in Borsa Istanbul stock exchange. To measure firm performance used indicators such as Return on Asset (ROA), Return on Equity (ROE) and Earning per Share (EPS) as well as Debt Ratio (DR) as capital structure variable. The results show that there is a negative significant relationship between capital structure and firm performance

Kubai (2016) carried out study on the effect of capital structure on the financial performance of manufacturing forms in Kenya from 2009-2015 using panel regression analysis. Secondary sources of data were employed and sourced from the financial statement of 10 selected firms. In measuring the dependent and independent variables, return on equity, total debt to total equity, liquidity size and growth of the firms were used. It was revealed a negative relation exists between total debt, size and financial performance which indicate using more of debt or assets are linked to a decrease in performance in financial perspective. The study additionally found out that financial performance improved with increase in liquidity and sales growth.

\section{Methodology}

The methodology approach for this study rest on ex-post facto research design. Secondary data was employed and sourced from the financial statement of the sampled manufacturing firms in the food industry in Nigeria and the time coverage covers a period from 2006-2016. In this study, dependent variable is proxy by efficiency ratio while independent variable is proxy by total debt and equity. The study employed long run relationship among the series using pedronipearan co-integration test while panel regression analysis is used as the estimation techniques.

\subsection{Model Specification}

To assess the nature and strength of the relationship between firms external financing and financial performance, two three models were developed each to test hypotheses of the study. Following the model specification of Yimka, Oguntolu and Adelakun (2015), the study adopts and adapt the model. The model states that

$\mathrm{ROA}=\mathrm{f}($ Eqt, Dbt), ROE =f (Eqt, Dbt), ROCE $=\mathrm{f}($ Eqt, Dbt)

To adapt this model, the study incorporate total debt as one of the variable for independent variable to ascertain joint effect of equity and debt on firm performance and used ratio of equity to total asset and ratio of debt to total asset rather than the face which may be biased. The new model for the study is therefore stated thus,

ROA $=f($ TETA, TDTA, LTDTA)

These models simply explain that all those dependent variables are subject to respective combination of equity and debt to determine performance. The explicit form of the model is stated thus;

ROA $_{t}=\beta_{1}$ TETA $_{t}+\beta 2$ TDTAt $_{t}+\beta_{3}$ LTDTA $+\mu_{t}$

Where,

$\mathrm{ROA}=$ Return on Asset,TETA $=$ Equity to total Asset, TDTA=Total Debt to total Asset, LTDTD =Long termDebt, $\mu_{\mathrm{t}=}$ Stochastic Error Term, $\beta_{0}=$ constant term, $\beta 1 \beta 2 \beta 3=$ parameters of the independent variables

\section{Discussion of Findings}

A critical scrutiny of the descriptive statistics for the dependent and explanatory variables discloses several issues. The mean value of the return on assets (ROA) for the sample as a whole is $11.63 \%$, while the highest mean from the series is recorded by TDTA at $69.51 \%$. ROA exhibits high volatility by $38.92 \%$ which may be as a result of the mixture of financing employed by the firms. It also revealed that variables examined are positively skewed which indicates that the distribution is has a long right tail. The kurtosis statistics shows that all the variables are above 3 which indicate that the distribution is peaked i.e. leptokurtic relative to normal test if the series are normally distributed. The null hypothesis of Jarque-Bera implies that the series are normally distributed. From the results it can be revealed that all the variables are above $5 \%$ level of significant which indicates that null hypothesis is retained i.e. the series are normally distributed 


\begin{tabular}{|c|c|c|c|c|}
\hline & ROA & TD_TA & TE_TA & LTD_TA \\
\hline Mean & 11.63196 & 0.695198 & 1.588163 & 1.272752 \\
\hline Median & 0.193642 & 0.081091 & 0.456978 & 0.112278 \\
\hline Maximum & 215.7936 & 9.877338 & 24.50956 & 27.45671 \\
\hline Minimum & -0.19427 & 0.00086 & -0.12605 & 0.000583 \\
\hline Std. Dev. & 38.92668 & 1.596203 & 4.148785 & 4.348924 \\
\hline Skewness & 3.957981 & 4.033347 & 4.125838 & 4.683559 \\
\hline Kurtosis & 18.73034 & 21.68817 & 20.72217 & 26.35311 \\
\hline Jarque-Bera & 710.6595 & 949.4815 & 875.7957 & 1450.879 \\
\hline Probability & 0 & 0 & 0 & 0 \\
\hline Sum & 639.758 & 38.2359 & 87.34895 & 70.00138 \\
\hline Sum Sq. Dev. & 81825.49 & 137.5846 & 929.4705 & 1021.31 \\
\hline Observations & 55 & 55 & 55 & 55 \\
\hline
\end{tabular}

Table 1: Summary of Descriptive Analysis

Source: Author Computation from Eviews, 9

\subsection{Correlation Matrix Result}

The correlation matrix for the variables is reported in Table 2 in order to examine the correlation that exists among the variables. According to Evans (1996), the strength of the correlation between variables can be known using absolute value of $\mathrm{R}$ which indicates that value between 0.00-0.19 has very weak correlation, 0.20-0.39 has weak correlation, 0.40-0.59 has moderate correlation, 0.60-.79 has strong correlation and 0.80-0.10 has very strong correlation. Based on these, the results show that there is a positive and strong correlation between return on assets(ROA) and manufacturing firm's financial performance proxy by TDTA, LTDTA and TETA by $94 \%, 90 \%$ and $78 \%$ respectively. The implication of the results indicate that, all debt and equity are great indicators determining the firm performance

\begin{tabular}{|c|c|c|c|c|}
\hline & ROA & TD/ TA & LTD/ TA & TE/ TA \\
\hline ROA & 1 & & & \\
\hline TD/TA & 0.940419 & 1 & & \\
\hline LTD/TA & 0.90213 & 0.948584 & 1 & \\
\hline TE/ TA & 0.784422 & 0.795 & 0.864629 & 1 \\
\hline
\end{tabular}

Table 2: Correlation Matrix

Source: Computation from Eviews, 9

In checking for long run relationship between the said variables i.e. ROA, TDTA, LTDTA TETA Pedroni residual cointegration test was employed in the estimation models. From Table 3 below, there exist three co-integration with $\mathrm{p}$-vale $0.006,0.005$ and 0.006 respectively which are all lesser than 55 level of significant. This indicates that there exist a long run relationship between external financing and manufacturing performance among the selected firms.

\begin{tabular}{|c|c|c|c|c|c|c|c|}
\hline & Statistic & Prob. & Statistic & Prob. & & Statistic & Prob. \\
\hline Panel v-Statistic & -0.77905 & 0.7820 & -1.088984 & 0.8619 & Group rho-Statistic & 1.626732 & 0.9481 \\
\hline Panel rho-Statistic & 0.284690 & 0.6121 & 0.839233 & 0.7993 & Group PP-Statistic & -2.50855 & 0.0061 \\
\hline Panel PP-Statistic & -2.489146 & 0.0064 & -1.558311 & 0.0596 & Group ADF-Statistic & 0.703180 & 0.7590 \\
\hline Panel ADF-Statistic & 0.177512 & 0.5704 & 0.041094 & 0.5164 & & & \\
\hline
\end{tabular}

Table 3: Summary of Long Run Relationship between ROA and Firm Performance

Source: Computation from Eviews, 9

\subsection{Panel Regression}

From the result in Table 5, the study employed both OLS panel and fixed panel regression to estimate the relationship between external financing and manufacturing performance. The results revealed that TDTA and TETA have positive relationship with manufacturing performance. Although TDTA is significant for both panel and fixed effect by (0.000) while TETA does not. The two different estimation models show similar results at same level of significance. In the same vein, LTDTA has a negative relationship with manufacturing performance. This result is supported by both OLS and fixed effect.

The $\mathrm{R}^{2}$ is high for both estimation models at 0.9270 and 0.8880 ; this indicates that about $92.70 \%$ and $88.80 \%$ of the variation in return on assets are explained by the variation in the explanatory variables of the studied firms. The Fstatistics and Durbin-Watson statistics are also significant; hence the estimated equation can be relied upon in making valid inference about the influence of the explanatory variables on the manufacturing performance in Nigeria 


\begin{tabular}{|c|c|c|}
\hline \multicolumn{3}{|c|}{ Dependent Variable: ROA } \\
\hline Independent Variables & Fixed Effects & Panel OLS \\
\hline Constant & $-5.8397(-1.2945)$ & $-5.8397(-1.2945)$ \\
\hline TDTA & $29.3495(7.8620)$ & $21.2499(5.8183)$ \\
\hline LTDTA & $-0.32912(-2.1078)^{*}$ & $-0.1314(-0.0081)^{*}$ \\
\hline TETA & $0.7914(1.0267)^{*}$ & $0.9794(1.1054)^{*}$ \\
\hline No. of Observations & 55 & 55 \\
\hline $\mathrm{R}^{2}$ & 0.9270 & 0.8880 \\
\hline F-Statistics & 85.29 & 134.89 \\
\hline Prob.(F-Statistics) & 0.0000 & 0.0000 \\
\hline D-Watson Statistics & 2.39 & 1.77 \\
\hline
\end{tabular}

Table 6: Estimation Results for L\&A for the Sample Banks for the Period 2006-2016

Note: * Significant at 5\% Level and Numbers in Parentheses are the Asymptotic T-Values of the Coefficient Source: Results Obtained from Data Analysis Using the E-Views Statistical Package

\section{Conclusion and Recommendations}

The study investigated the joint effects of TDTA, LTDTA TETA on the performance of the manufacturing firms' in Nigeria using secondary sources of data sourced from the financial statement of the manufacturing firms that are in food industry within the time scope of 2006-2016. Empirically, the study employed descriptive statistics to know the characteristics of each variable. Also, correlation matrix was used to establish if relationship exist between the series. Co integration test also was carried out using Pedroni Residual co integration test while panel OLS and Fixed Effect test was employed as the estimation technique. Findings revealed that, strong relationship exists between the two variables and long run relationship was also revealed. The panel data result using OLS and Fixed effect exhibited same results which revealed that, TDTA TETA have positive relationship with manufacturing firm performance while LTDTA has negative relationship and not significant at $5 \%$. The study therefore makes general inference that external financing increases firm performance in Nigeria.

Based on these empirical findings, the study recommends that, the manufacturing firms in Nigeria should employed mixture of equity and debt in their financing options while debt should be kept at a barest minimum to guide againstcompany being over levered which may result in financial distress in the long run as it is indicated from the results obtained. This position is in line withChechet and Olatiwola (2014), Haniama (2014) and Alalade et al, (2015) and Ubesie(2016).

\section{References}

i. Alalade, S.A., Oguntodu, J.A. \& Adelakin, V.A. (2015). Firms' capital structure and profitability performance: a study of selected food product companies in Nigeria. International Journal of Banking and Finance Research, 1(8), 64-83

ii. Barbosa, N., \& Louri, H. (2005). corporate performance: does ownership matter? a comparison of foreign- and domestic-owned firms in Greece and Portugal. Review of Industrial Organization, 27(1),73-102

iii. Bashiru, M., \& Bukar, M. (2016).the impact of capital structure on financial performance of listed firms in the Nigerian oil and gas industry. International Journal of Public Administration and Management Research, 3(4), 3844

iv. Brigham, E. \&Gapenski, L. (1978). Optimal financial policy and firm valuation. Journal of Finance, 39, 593-607

v. Dare, F.D., \& Sola, O. (2010). Capital structure and corporate performance in Nigeria petroleum industry: Panel Data Analysis. Journal of Mathematics and Statistics 6 (2), 168-173.

vi. Elena, T. (2012). External sources of finance for the corporate sector in Macedonia. Master Thesis submitted to faculty of Economics, University of IJUBIJANA

vii. Erasmus, P. D. (2008). Evaluating value based financial performance measures. Dissertation presented for the degree of Doctor of Philosophy at

viii. Stellenbosch University

ix. Habimana, O. (2014). Capital structure and financial performance: evidence from firms operating in emerging markets. International Journal of Academic Research in Economics and Management Sciences, 3(6), 159- 165

x. Hillier, D., Clacher, I., Ross, S., Wester field, R., Jaffe, J., \& Jordan, B. (2011). Fundamentals of corporate finance: McGraw-Hill

xi. Kubair, F.B (2016). The effect of capital structure on the financial performance of manufacturing firms in kenya. a research project submitted in partial fulfillment of the requirements for the award of master of science in finance, university of Nairobi

xii. Modigliani F, \&Miller. M.H. (1958) The cost of capital, corporation finance and the theory of investment. The American Economic Review, 48, 261-297 
xiii. Mohammed, A. H. (2017). Effect of financial leverage on financial performance of manufacturing and allied firms at Nairobi securities exchange

xiv. Nassar, S. (2010). The impact of capital structure on Financial Performance of the firm in Borsa Istanbul. Journal of Business \& Financial Affairs, 5(2), 1-4

xv. Obi, C.E., \& Imo, G.I. (2016). The Impact of external financing on dividend per share of quoted manufacturing firms in Nigeria. Journal of Applied Finance \& Banking, 6(3),40-51

xvi. Oloyede, J.A. \& S.O. Akinmulegun. (1999). Effect of capital structure on corporate performance of selected quoted companies in Nigeria: A preliminary investigation. Nigeria Journal of Banking and Finance, 2, 119-128

xvii. Ololade, S.A., Omotosho, O., \& Adeniyi, S.D. (2017). Effect of capital structure on the performance of Nigerian listed manufacturing firms. European Journal of Business and Management, 9(7), 22-32

xviii. Ong, T. S., \& Teh, B. H. (2011). Capital structure and corporate performance of Malaysian construction sector. International Journal of Humanities and Social Science, 1(2), 28-36

xix. Onyango, J.A. (2016). The effects of external financing on the growth of savings and credit cooperative societies' wealth in Nairobi County, Kenya. A Research Project Report Submitted to the Chandaria School of Business in Partial Fulfillment of the Requirement for the Degree of Masters in Business Administration

xx. Pandey IM (1999) Financial Management. (11th ed), Vikas Publishing House Pvt Ltd, New Delhi, India.

xxi. Saleemi, N. A. (2009). Entrepreneurship Simplified .Nairobi, Kenya: N.A. Saleemi Publications

xxii. Ubesie, M.C. (2016). The effect of capital structure on the financial performance of Nigeria quoted conglomerates. European Journal of Accounting, Auditing and Finance Research, 4(6), 61-69

xxiii. Udoayang, J.O \& Asuquo, A.I. (2008). Analysis of the Impact of Corporate Income Tax on Investment/ Financing Decision of Selected Quoted companies in Nigeria.Journal of Financial Economics 39(3), 375-592 